\title{
Identification of Taxonomic Status of Spiny Lobster Species in Sri Lanka Using DNA Barcoding and its Implications on Fisheries and Conservation Programs
}

\author{
J.D.M. Senevirathna and D.H.N. Munasinghe ${ }^{1 *}$ \\ Department of Zoology \\ Faculty of Science \\ University of Ruhuna, Sri Lanka
}

\begin{abstract}
Lobster fishery is one of the most economically important marine coastal fishing activities. However, genetic identification and taxonomic status of available lobster species are poorly understood in Sri Lanka. The DNA barcoding based on the amplification of partial mitochondrial Cytochrome oxidase I (COI) gene region provides an effective approach for the rapid identification of species status and evaluation of species richness. The present study attempted to collect genetic information of barcoding region for five spiny lobster species that are available in the southern coast of Sri Lanka and to estimate the phylogenetic relationships with the data available for relevant spiny lobsters of other geographic locations. For this purpose, additional sequences were downloaded from the NCBI Genbank and phylogenetic trees were constructed using Maximum Parsimony, Maximum Likelihood and Neighbour Joining methods. Identical tree topologies were resulted from the three methods, and three major clades could be identified. The first clade consisted of Panulirus penicillatus $+\underline{P}$. longipes. Panulirus $\underline{\text { homarus }}+\underline{P}$. versicolor $+\underline{P}$. ornatus were grouped into the second clade whereas the third clade included $\underline{P}$. homarus + $\underline{P}$. penicillatus $+\underline{P}$. longipes. It is important to observe that $\underline{P}$. homarus samples collected from southern Sri Lanka grouped with both sub species $\underline{P} \underline{\underline{h}} \underline{\underline{\text { homarus }}}$ and $\underline{\underline{P}} \underline{\underline{h}} \underline{\underline{\text { megasculpta}}}$ indicating their availability in the sampling regions. Although three subspecies are available in $\underline{P}$. longipes, the samples from southern Sri Lankan grouped only with $\underline{P} . \underline{l} \underline{\text { longipes. High }}$ intra-specific nucleotide diversity was reported in for Sri Lankan samples. This indicates that habitats around southern coast of Sri Lanka possess suitable environmental conditions to inhabit diverse Panulirus populations. These results would be highly useful to plan management and conservation strategies for Panulirus populations in Sri Lanka.
\end{abstract}

Keywords: COI gene, DNA barcoding, southern Sri Lanka, spiny lobsters, taxonomy

\section{INTRODUCTION}

Lobsters of family Palinuridae are popular as a delicious seafood variety all over the world. Due to its high commercial value, lobster species have been rapidly exploited since last few decades and the future of the lobster fishery is uncertain (Bondad-Reantaso et al., 2012). Within the family Palinuridae, 19 Panulirus species have been described to date, some of which are divided into subspecies (Holthuis, 1991; George, 1997; Sarver et al., 1998). In the spiny lobster genus Panulirus White (1847) has shown a high level of species diversity and

\footnotetext{
1 Department of Zoology, Faculty of Science, University of Ruhuna, Matara, Sri Lanka.

Corresponding author: dhnm@ ruh.ac.lk
} 
wide geographic distribution thus, many species are important in commercial fisheries (Margaret et al., 2001).

Lobster fishery is an ancient fishing industry in Sri Lanka in which two main types of lobster groups are important i.e. spiny lobsters and slipper lobsters. The availability of six spiny lobster species has been recorded in Sri Lankan seas (Jayawickrama, 1991) as Panulirus homarus (Linnaeus), P. ornatus (Fabricius), P. versicolor (Latrelle), P. longipes (A. MilneEdwards), P. polyphagus (Herbst) and P. penicillatus (Oliver). According to previous studies, South coast of Sri Lanka houses all six species (Jayakody, 1989). However, currently only five species, except $P$. polyphagus, can be found in the southern coastal belt of Sri Lanka (Upul, 2009). Southern coastal lobster market is export-oriented and only small proportion of the catch goes to local market, especially for tourist hotels. It has been reported that from mid-eighties that the lobster fishery of the country is on the decline and therefore, a number of regulations have been imposed to protect the lobster fishery industry (Abayasekera \& Madhavie, 2003; 2004; Gazette no. 1601/36, 15/05/2009).

Currently, the demand for lobsters is high and further increasing, which cannot be met only from natural resources. As a solution, the National Aquaculture Development Authority (NAQDA) in Sri Lanka is planning to launch breeding and culturing programs for economically important lobster species. For such programs, brood stocks need to be collected from the wild populations. Therefore, understanding of genetic structures of wild populations are essential prior to implement these programs.

Although lobster fishery industry makes a significant impact on the socio-economic development on the southern coastal region of Sri Lanka (Koralagama et al., 2007), limited information is available on the species availability and their genetic composition. Few studies carried out in the past have been based on aspects such as population structure and regulations for lobster fishery industry (Amarakoon et al., 2006 a,b; Gunawardane et al., 2006 a,b). A recent study by Senevirathna \& Munasinghe (2012) has revealed the taxonomic status of four Panulirus species that are available in the southern coast of Sri Lanka using mitochondrial 16SrRNA gene region. With modern molecular techniques, genetic identification of economically important species can be documented and can be utilized in fisheries (aquaculture) and conservation programs. The use of molecular markers has contributed significantly to find solutions in agriculture practices (Jena \& Mackill, 2008). The DNA barcoding is a novel system designed to provide rapid, accurate, and automatable species identifications by using short, standardized gene regions of mitochondrial Cytochrome Oxidase I (COI) gene (Herbert \& Gregory, 2005; Casiraghi et al., 2010). The DNA barcoding procedure helps to accelerate the discovery of new species, improve the quality of taxonomic information and make information readily available to non-taxonomists and researchers in general (Hebert et al., 2003; Stoeckle, 2003). Lorenz et al. (2005) have suggested that depositing barcode sequences in a public database, along with primer sequences, trace files and associated quality scores, would make this technique widely accessible for species identification and biodiversity analysis. This paper reports the phylogenetic status of five lobster species available in southern coast of Sri Lanka using molecular barcoding using mitochondrial COI region and importance of the findings in fisheries industry in Sri Lanka. 


\section{METHODOLOGY}

\section{Sample collection and preservation}

Adult spiny lobsters were collected from fish landing stations of Kirinda, Godawaya, Waligama and Hikkaduwa of southern coastal belt in Sri Lanka (Fig. 1). The lobster samples collected ( $P$. homarus $-11, P$. versicolor $-4, P$. longipes $-4, P$. ornatus $-1, P$. penicillatus $-1)$ and their localities are given in the Table 1. Lobster species were identified according to De Bruln et al. (1991). Tissue samples were collected from pereiopods for molecular analysis and were preserved in $95 \%$ ethanol. Reference materials were stored at the Research Laboratory of Department of Zoology, University of Ruhuna for further research work.

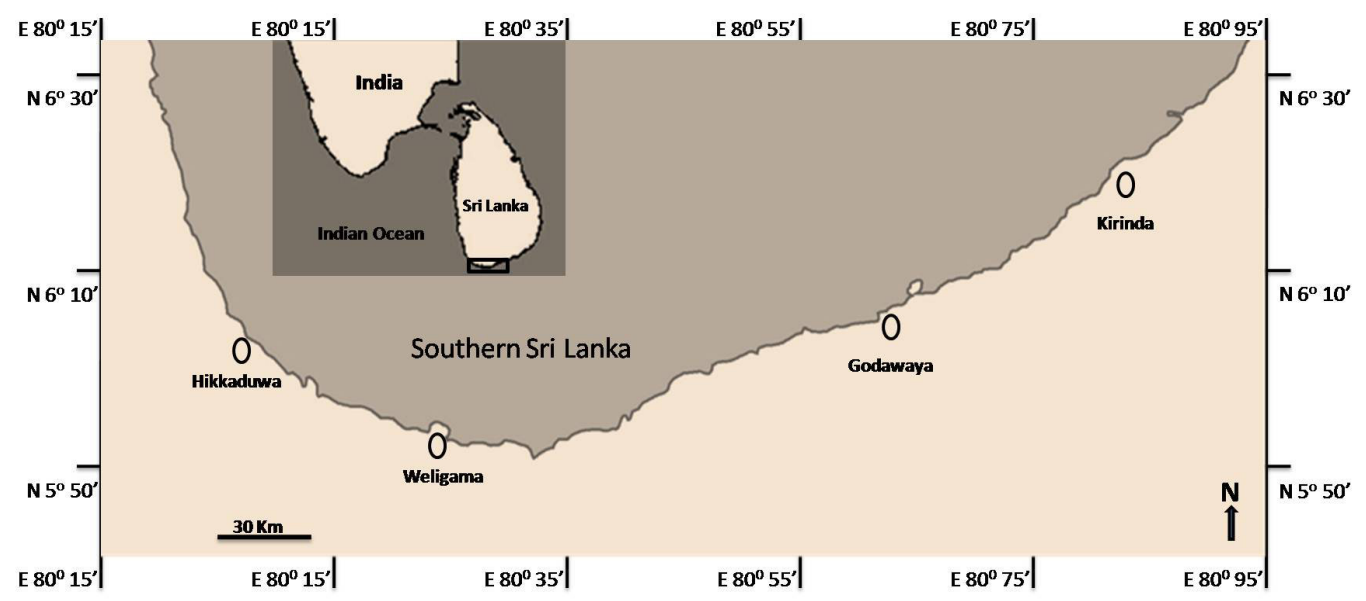

Fig. 1. Sampling sites of four different populations of spiny lobsters in southern coast of Sri Lanka.

\section{DNA extraction, amplification and sequencing}

The DNA extraction was performed using the Genomic DNA extraction Kit (Promega Wizard, 2003). Amplification of partial mitochondrial COI (658 bp) gene was accomplished using universal primers namely, LOC1490 and HCO2198 (Folmer et al., 1994). Amplification was carried out with $100 \mathrm{ng}$ of genomic DNA in a reaction containing $5 \mathrm{U}$ of Taq polymerase (Invitrogen ${ }^{\mathrm{TM}}$ ), $10 \mathrm{X}$ buffer, $0.5 \mu 110 \mathrm{mM}$ of each primer and $1 \mu 12.5 \mathrm{mM}$ dNTPs. The PCR thermal profile used was comprised of an initial step of 3 min at $94{ }^{\circ} \mathrm{C}$, next 5 cycles at $30 \mathrm{sec}$ at $94^{\circ} \mathrm{C}, 40 \mathrm{sec}$ at $45^{\circ} \mathrm{C}$, and $1 \mathrm{~min}$ at $72^{\circ} \mathrm{C}$ and $30 \mathrm{cycles}$ at $30 \mathrm{sec}$ at $94^{\circ} \mathrm{C}, 40 \mathrm{sec}$ at $53^{\circ} \mathrm{C}$, and $1 \mathrm{~min}$ at $72^{\circ} \mathrm{C}$ following final extension at $72^{\circ} \mathrm{C}$ for $3 \mathrm{~min}$. The amplified PCR products (Fig. 2) were enzymatically purified with EXO/SAP and the sequences were obtained using the Big-Dye Terminator V.3.1. Cycle Sequencing Kit (Applied Biosystems, Inc.) was mounted on a capillary sequencer (ABI 3130 Genetic analyzer). Sequencing reactions were carried out at the scientific and technical services of the Paul Herbert centre for DNA Barcoding and biodiversity studies, Aurangabad, India. 


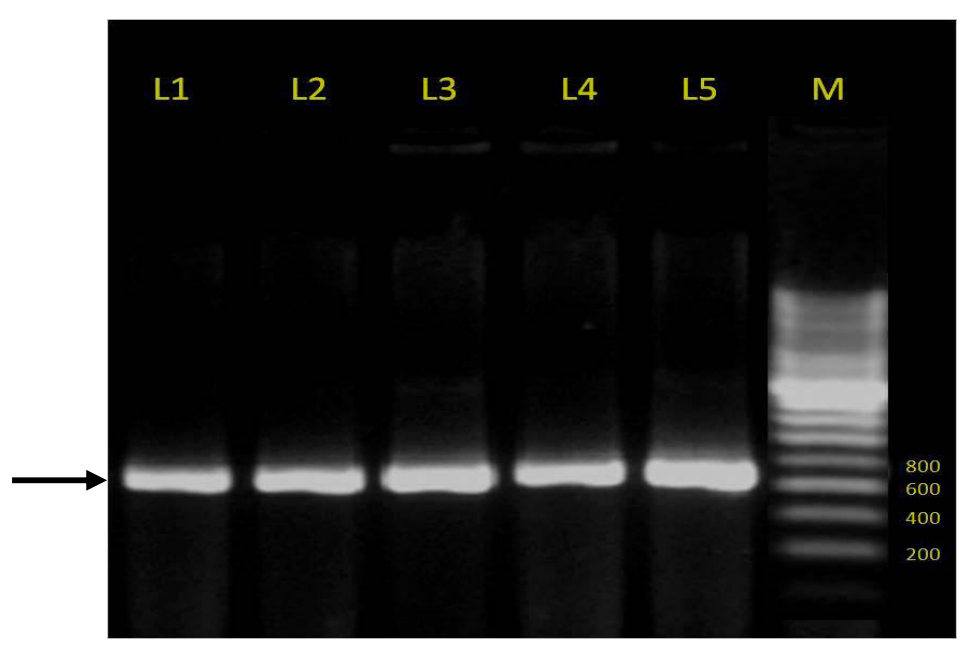

Fig. 2. Amplified PCR products (indicated by an arrow) of five different Panulirus species; L1 - P. homarus, L2 - P. ornatus, L3 - P. longipes, L4 - P. versicolor, L5 - P. penicillatus and M -DNA marker.

\section{Alignment and phylogenetic analyses}

As there was only one sample available for $P$. ornatus and $P$. penicillatus from southern sea of Sri Lanka, the phylogenetic analyses were carried out excluding sequences of these two species. Additional sequence data were downloaded from the NCBI GenBank and information is given in Table 2. Sequences were edited and aligned using Codon code aligner 4.0 (Codon Code Corporation., 2012). Forty eight sequences were used to construct the data set and Jasus edwardsii was used as the outgroup species (Fig. 3). Analyses were carried out using three tree building methods namely, the Maximum Parsimony (MP), Maximum Likelihood (ML) and Neighbor Joining (NJ). The MP method was carried out using tree bisection reconnection option. For the ML analysis, HKY model was used as nucleotide substitution model and the NJ analysis was carried out using p-distance method. The reliability of clusters of the phylogenetic tree was evaluated using bootstrap test with 1000 replicates. Analyses were carried out using MEGA 5.1. (Tamura et al., 2011) and all generated sequences were uploaded to BOLD system and published on the GenBank (KF548568 - KF548586). 
Table 1. Locality, BOLD accession and NCBI identification of Sri Lankan samples.

\begin{tabular}{llcccc}
\hline Code & \multicolumn{1}{c}{ Species } & Location & $\begin{array}{c}\text { BOLD } \\
\text { Accession }\end{array}$ & $\begin{array}{c}\text { NCBI } \\
\text { Identification }\end{array}$ & $\begin{array}{c}\text { NCBI ID } \\
\text { reference }\end{array}$ \\
\hline gphh1 & Panulirus homarus homarus & Godawaya & JDMS014-13 & $99 \%$ & JQ229918.1 \\
gphh2 & Panulirus homarus homarus & Godawaya & JDMS003-13 & $99 \%$ & JQ229926.1 \\
gphh3 & Panulirus homarus homarus & Godawaya & JDMS023-13 & $99 \%$ & JQ229888.1 \\
kphh1 & Panulirus homarus homarus & Kirinda & JDMS017-13 & $100 \%$ & JQ229916.1 \\
kphh2 & Panulirus homarus homarus & Kirinda & JDMS016-13 & $99 \%$ & JQ229926.1 \\
wphh1 & Panulirus homarus homarus & Weligama & JDMS019-13 & $100 \%$ & JQ229885.1 \\
wphh2 & Panulirus homarus homarus & Weligama & JDMS022-13 & $99 \%$ & JQ229883.1 \\
hphh1 & Panulirus homarus homarus & Hikkaduwa & JDMS021-13 & $99 \%$ & JQ229883.1 \\
hphh2 & Panulirus homarus homarus & Hikkaduwa & JDMS015-13 & $99 \%$ & JQ229921.1 \\
hphh3 & Panulirus homarus homarus & Hikkaduwa & JDMS018-13 & $100 \%$ & JQ229926.1 \\
hphh4 & Panulirus homarus homarus & Hikkaduwa & JDMS020-13 & $99 \%$ & JQ229923.1 \\
hpl11 & Panulirus longipes longipes & Hikkaduwa & JDMS005-13 & $98 \%$ & JQ229879.1 \\
kpl11 & Panulirus longipes longipes & Kirinda & JDMS008-13 & $97 \%$ & JQ229879.1 \\
kpl12 & Panulirus longipes longipes & Kirinda & JDMS009-13 & $99 \%$ & JQ229879.1 \\
kpl13 & Panulirus longipes longipes & Kirinda & JDMS011-13 & $97 \%$ & JQ229879.1 \\
hpv1 & Panulirus versicolor & Hikkaduwa & JDMS007-13 & $100 \%$ & JN418936.1 \\
kpv1 & Panulirus versicolor & Kirinda & JDMS010-13 & $100 \%$ & JQ229882.1 \\
wpv1 & Panulirus versicolor & Weligama & JDMS024-13 & $100 \%$ & JQ229882.1 \\
wpv2 & Panulirus versicolor & Weligama & JDMS012-13 & $100 \%$ & JQ229882.1 \\
hpo1 & Panulirus ornatus & Hikkaduwa & JDMS013-13 & $84 \%$ & AF339467.1 \\
hpp1 & Panulirus penicillatus & Hikkaduwa & JDMS006-13 & $99 \%$ & JN701684.1 \\
\hline
\end{tabular}

Table 2. Locality information and GenBank Accession Numbers of the sequences downloaded from NCBI GenBank data.

\begin{tabular}{lcc}
\hline Species & Location & GenBank Accession No. \\
\hline Panulirus penicillatus & Pacific ocean & AB610676.1 \\
Panulirus penicillatus & Ecuador & AB576722.1 \\
Panulirus penicillatus & Pacific ocean & AB193081.1 \\
Panulirus penicillatus & Pacific ocean & AB193072.1 \\
Panulirus penicillatus & Palau Is. & AF339468 \\
Panulirus penicillatus & Pacific ocean & AB610707.1 \\
Panulirus penicillatus & Pacific ocean & AB610698.1 \\
Panulirus longipes bispinosus & Pacific ocean & AB193084.1
\end{tabular}


Panulirus longipes longipes

Panulirus longipes bispinosus

Panulirus longipes bispinosus

Panulirus longipes longipes

Panulirus longipes bispinosus

Panulirus longipes femoristriga

Panulirus longipes longipes

Panulirus versicolor

Panulirus ornatus

Panulirus ornatus

Panulirus homarus megasculpta

Panulirus homarus

Panulirus homarus homarus

Panulirus homarus homarus

Panulirus homarus homarus

Panulirus homarus homarus

Panulirus homarus

Panulirus homarus homarus

Panulirus homarus homarus

Panulirus homarus

Jasus edwardsii
Pacific ocean

AB193083.1

Pacific ocean

AB193080.1

Pacific ocean

AB193075.1

Pacific ocean

AB193074.1

Pacific ocean

AB193071.1

Torres Strait, Australia

AF339463

Philippines

AF339464

Palau Is.

AF339472.1

Torres Strait, Australia

AF339467.1

Pacific ocean

JN591362.1

Sadh, Oman

AF339458.1

Spain

FJ174963.1

India: Kollam, Kerala

JQ229885.1

India: Kollam, Kerala

JQ229884.1

India: Kollam, Kerala

JQ229886.1

India: Vizag, Andhra Pradesh

JQ229887.1

China

JN591360.1

India: Vizag, Andhra Pradesh

JQ229888.1

Marquesas Is.

AF339457.1

Philippines

AF508160.1

Fiordland, New Zealand

\section{RESULTS AND DISCUSSION}

Amplification of partial COI gene region generated single amplification products in both directions that had an average length of approximately $658 \mathrm{bp}$. The COI gene sequence was chosen as it represents common features that are typically used for species identification of metazoans (Hebert \& Gregory, 2005; Tanya \& Kumar, 2010). Mitochondrial COI gene region has been frequently used to study phylogeny and biogeography of crustaceans (Tam \& Kornfield, 1998; Sarver et al., 1998; Arif \& Khan, 2009, Maria et al., 2012). All three tree building methods produced almost similar tree topologies thus, only ML tree is presented here (Fig. 3).

Analyses produced three clades in the phylogenetic tree and gather species into major groups. The first clade consisted of $P$. penicillatus $+P$. longipes species. $P$. homarus $+P$. versicolor $+P$. ornatus have been grouped into the second clade. The third clade grouped $P$. homarus $+P$. penicillatus $+P$. longipes species. The percentage of sequence distance levels (P distance) resulted from this study for Panulirus species that collected from southern coast of Sri Lanka is given in the Table 3.

According to the phylogenetic tree, sequences of $P$. homarus were grouped under the three clades. Among them $P$. homarus recorded from Chinese water has made a sister clade to the $P$. longipes and P. penicillatus that was recorded from the Pacific Ocean. Marquesas island 
together with $P$. ornatus collected from southern Sri Lanka has made a sister clade to $P$. homarus group. This linage is consisted majority of $P$. homarus sequences including southern Sri Lankan samples. Other two sequences of $P$. ornatus that reported from Pacific Ocean grouped together but differ by $5.2 \%$ distance level.

The $P$. homarus samples collected from southern Sri Lanka grouped with both subspecies showing that both subspecies are available in southern Sri Lankan seas. Taxonomic status of these samples was further confirmed by matching their sequences with the sequences available in the Genbank using Blast algorithm (Table 1). This observation was also discussed in the past study conducted by Senevirathna \& Munasinghe (2012). The reported mean genetic distance between two $P$. h. homarus and $P$. h. megasculpta sub species ranged from $0.2 \%$ to $1.9 \%$. The distance levels between Sri Lankan P. homarus samples, which grouped with two sub species in this study $(0.2 \%$ and $2.6 \%)$, were marginally higher than the previously recorded values.

Two genetically different groups have been reported for $P$. longipes. Both clades have made sister connections with $P$. penicillatus groups. Three sub species have been recorded for $P$. longipes as P. l. longipes, P. l. bispinosus and P. l. femoristriga. All southern Sri Lankan samples gather to form one group and joined with sub species $P$. l. longipes. Nucleotide distance among $P$. longipes sequences derived from Southern Sri Lanka samples ranged from $0.4 \%$ to $3.7 \%$.

The phylogenetic tree produced two clades for P. penicillatus indicating that there are two phylogenetically different groups available in the Pacific Ocean. Only one COI sequence was recorded in the Genbank for $P$. versicolor. All $P$. versicolor samples grouped together and formed one clade which supported by high bootstrap value. Genetic distance within $P$. versicolor group ranged from $0.2 \%$ to $0.8 \%$.

The present study indicated the utility of partially amplified mitochondrial COI gene region to identify Sri Lankan spiny lobster species of the genus Panulirus. Investigation of intraspecific variation may be essential for species identification, and larger sample sizes for several species would be useful to further confirm the DNA barcoding. Utility of molecular identification for species delineating has been recorded for other crustacean species (Maria et al., 2012; Imai et al., 2004) including lobster species (Seinen et al., 2006; Ptacek et al., 2001; Ravago \& Juinio-Menez, 2003; Sekiguchi, 1986). Barcoding information facilitate to improve the production in agriculture through identification of cryptic species (Hebert et al., 2004; Kress et al., 2005; Cohen et al., 2009), control parasitic diseases through reliable identification of parasite species (Beskansky et al., 2003; Smith et al., 2006) and genetic improvement of culturing species (Ogden, 2008; Linda \& Paul, 1995). Documentation of genetic information of ecologically and economically important species can be utilized in future development and conservation programs as the ability of barcodes to identify fragments of life has applications ranging from the resolution of cases of species substitution in the marketplace (Marko et al., 2004; Moura et al., 2008) to the protection of food security. Moreover, barcodes enable the rapid comparison of multiple taxa from widespread geographic regions and for detecting broad-scale biogeographic patterns. This study raveled the taxonomic status of spiny lobsters that can be found at present in the southern coast of Sri Lanka and by publishing barcoding information in the BOLD system, contributing to the global DNA barcode initiative program. 
DNA barcoding of spiny lobster species in Sri Lanka

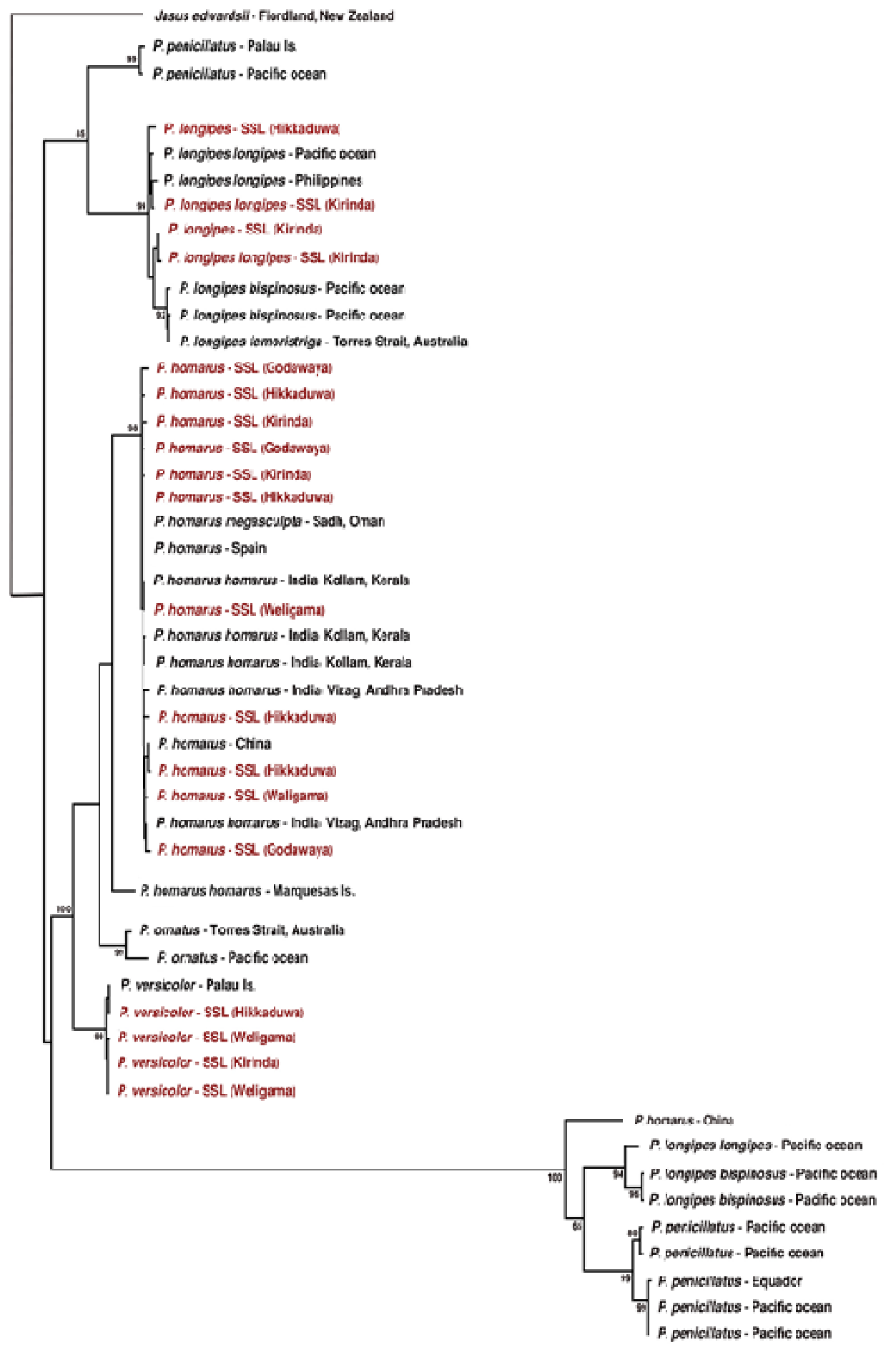

Fig. 3. The genus-specific ML tree derived from analyses of COI gene region of Panulirus species. 


\section{CONCLUSIONS}

The present study the utilized DNA barcoding data to delineate Sri Lankan spiny lobster species of the genus Panulirus. This study revealed the availability of species/sub species status of genus Panulirus in the southern coast of Sri Lanka providing important information for fisheries industry and conservation programs. A high intraspecific genetic variation was reported especially for $P$. homarus indicating the possibility of collecting suitable brood stocks for future culturing programs of this species.

\section{ACKNOWLEDGEMENTS}

This study was supported by the grant TURIS - RU/DVC/Pro 45 offered from University of Ruhuna and OSTP/2012/28 offered from the National Science Foundation (NSF) of Sri Lanka. The authors would like to thank the Director and the team of Paul Herbert Centre for DNA Barcoding and Biodiversity studies, Aurangabad, India for technical support and guidance provided during this study.

\section{REFERENCES}

Abayasekera, C.R. and Madhavie, A.V.K. (2003, 2004). Open access, over-fishing and livelihood risk: a property rights perspective on the south coast lobster fishery in Sri Lanka. The Sri Lanka Journal of the Humanities. XXIX \& XXX (1\&2), 131-156.

Amarakoon, A.M.W.M.S.P., Jayakody, D.S. and de Croos, M.D.S.T. (2006a). Biology, population parameters and status of an unexploited lobster stock Puerulus sewelli Ramadan, 1938) in Sri Lanka. $4^{\text {th }}$ Food and Nutrition symposium. Faculty of Livestock, Fisheries and Nutrition, Wayamba University of Sri Lanka. pp. 9.

Amarakoon, A.M.W.M.S.P., Jayakody, D.S. and de Croos, M.D.S.T. (2006b). Some observations in the deep sea lobster Puerulus sewelli on the south and south eastern waters of Sri Lanka. Abstract, SLAFAR, twelfth Annual Scientific Session. pp. 2.

Arif, I.A. and Khan, H.A. (2009). Molecular markers for biodiversity analysis of wildlife animals: a brief review. Animal Biodiversity and Conservation. 32.1, 9-17.

Beskansky, N.J., Severson D.W. and Ferdig M.T. (2003). DNA barcoding of parasites and invertebrate disease vectors: What you don't know can hurt you. Trends Parasit. 19, 545-546.

Bondad-Reantaso, M.G., Subasinghe, R.H., Josupeit, H., Cai, J. and Zhou, X. (2012). The role of crustacean fisheries and aquaculture in global food security: past, present and future. J. Invertebr. Pathol. 110, 158-165.

Casiraghi, M., Massimo, L., Emanuele, F., Andrea, G. and Fabrizio De M. (2010). DNA barcoding: theoretical aspects and practical applications. Tools for Identifying Biodiversity: Progress and Problems. pp. 269-273.

Codon Code Aligner, Dedham, MA, USA. (2012). Available at http://www.codoncode.com/ aligner/ 
Cohen, N.J., Deeds, J.R., Wong, E.S., Hanner, R.J., Yancy, H.F. (2009). Public health response to puffer fish (Tetrodotoxin) poisoning from mislabeled product. J. Food Prot. 72, 810-817.

De Bruln, G.H.P., Russall, B.C. and Bogusch, A. (1991). The marine fishery resources of Sri Lanka (FAO species identification field guide for fishery purposes). Food an Agricultural Organization of United Nations, Rome.

Folmer, O., Black, M., Hoeh, W., Lutz, R. and Vrijenhoek, R. (1994). DNA primers for amplification of mitochondrial cytochrome c oxidase subunit I from diverse metazoan invertebrates. Mol. Mar. Biol. Biotechnol. 3, 294-297.

Gazette no. 1601/36, 15/05/ (2009). The gazette of the Democratic Socialist Republic of Sri Lanka. Fisheries and aquatic resources act No. 02 of 1996.

George, R.W. (1997). Tectonic plate movements and the evolution of Jasus and Panulirus spiny lobsters (Palinuridae). Mar. Freshwat. Res. 48, 1121-30.

Gunawardane, P.V.S., Jayakody, D.S. and de Croos, M.D.S.T. (2006a). A study on adequacy of regulations for the spiny lobster fishery on the south coast of Sri Lanka. $4^{\text {th }}$ food and Nutrition symposium. Faculty of Livestock, Fisheries and Nutrition, Wayamba University of Sri Lanka. pp. 10.

Gunawardane, P.V.S., Jayakody, D.S. and de Croos, M.D.S.T. (2006b). Relevance and applicability of existing regulations for the spiny lobster fishery on the south coast of Sri Lanka. SLAFAR twelfth Annual Scientific Session. pp. 8.

Hebert, P.D.N., Cywinska, A., Ball, S.L. and de Waard, J.R. (2003). Biological identifications through DNA barcodes. Proc. R. Soc. Lond. B. Biol. Sci. 270, 313-321.

Hebert, P.D.N., Penton, E.H., Burns, J.M., Janzen, D.H. and Hallwachs, W. (2004). Ten species in one: DNA barcoding reveals cryptic species in the neotropical skipper butterfly Astrapes fulgerator. Proc. Natl. Acad. Sci. U S A. 101, 14812-14817.

Hebert, P.D.N. and Gregory, T.R. (2005). The Promise of DNA Barcoding for Taxonomy. Syst. Biol. 54(5), 852-859.

Holthuis, L.B. (1991). FAO Species catalogue. 13. Marine lobsters of the world. An annotated and illustrated catalogue of species of interest to fisheries known to date. FAO Fisheries Synopsis 125, 1-292.

Imai, H., Cheng, J.H., Hamasaki, K. and Numachi, K. (2004). Identification of four mud crab species (genus Scylla) using ITS-1 and 16S rDNA markers. Aquat. Living Resour. 17, 3134.

Jayakody,, D. S. (1989). Size at onset of sexual maturity and onset of spawning in female Panulirus homarus (Crustacea: Decapoda: Palinuridae) in Sri Lanka. Marine Ecology Progress Series. 57, 83-87.

Jayawickrama, S.J.C. (1991). Fishery and Population Dynamics of Panulirus homarus (Linnaeus) from Mutwal, Sri Lanka. J. Natn. Sci. Coun. Sri Lanka 19(1), 53-62. 
Jena, K.K. and Mackill, D.J. (2008). Molecular markers and their use in marker-assisted selection in rice. Crop Sci. 48, 1266-1276.

Kress, W.J., Wurdack, K.J., Zimmer, E.A., Weigt, L.A. and Janzen D.H. (2005). Use of DNA barcodes to identify flowering plants. Proc. Natl. Acad. Sci. U S A. 102, 8369-8374.

Koralagama, D.N., Amarasinghe, O. and Jayakody, S. (2007). Export market of lobsters in Sri Lanka, with special reference to slipper lobsters. Proceedings of the fourth academic sessions (NARA). pp. 84-90.

Linda, K.P and Paul, M. (1995). Developments in molecular genetics techniques in fisheries. In: G.R. Carvalho and T.J. Pitcher, Eds., Molecular Genetics in Fisheries, Chapman and hall, London.

Lorenz, J.G., Jackson, W.E., Beck, J.C. and Hanner, R. (2005). The problems and promise of DNA barcodes for species diagnosis of primate biomaterials. Philosophical Transactions of the Royal Society London B: Biol. Sci. 360, 1869-1877.

Margaret, B., Ptacek, A.D., Shane, K., Sarver, B., Michael, J., Childress, A., William, F. and Herrnkind, C. (2001). Molecular phylogeny of the spiny lobster genus Panulirus (Decapoda: Palinuridae). Mar. Freshwater Res. 52, 1037-47.

Maria, M., Bauza, R., Carlos, J., Francesco, N., Pedro, O., Joan, P. and Damia, J. (2012). Mitogenomic phylogenetic analysis supports continental-Scale variance in Subterranean Thalassoid Crustaceans. Curr. Biol. 22, 2069-2074.

Marko, P.B., Lee, S.C., Rice, A.M, Gramling, J.M., Fitzhenry, T.M., McAlister, J.S., Horn, G.R. and Moran, A. L. (2004). Mislabeling of a depleted reef fish. Nature 430, 309-310.

Moura, T., Silva, M.C., Figueiredo, I., Neves, A., Munoz, P.D. (2008). Molecular barcoding of north-east Atlantic deep-water sharks: species identification and application to fisheries management and conservation. Mar. Freshwat. Res. 59, 214-223.

Ogden R. (2008). Fisheries forensics: the use of DNA tools for improving compliance, traceability and enforcement in the fishing industry. Fish Fish. 9, 462-472.

Promega Wizard (2003). Available at http://www.flmnh.ufl.edu/soltislab/Soltis_site /Protocols_files/Promega_DNA_extraction.pdf

Ptacek, M.B., Sarver, S.K., Childress, M.J. and Herrnkind, W.F. (2001). Molecular phylogeny of the spiny lobster genus Panulirus (Decapoda: Palinuridae). Mar. Freshwat. Res. 52, 1037-1047.

Ravago, R.G. and Juinio-Menez, M.A. (2003). Phylogenetic position of the striped-legged forms of Panulirus longipes (A. Milne-Edwards, 1868) (Decapoda, Palinuridae) inferred from mitochondrial DNA sequences. Crustaceana 75, 1047-1059.

Sarver, S.K., Silberman, J.D. and Walsh, P.J. (1998). Mitochondrial DNA sequence evidence supporting the recognition of two subspecies or species of the Florida spiny lobster Panulirus argus. J. Crust. Biol. 18, 177-86. 
Seinen, C., Nobuaki, S., Hideyuki, I. and Taku, Y. (2006). Molecular species identification of spiny lobster phyllosoma larvae of the Genus Panulirus from the Northwestern Pacific. Mar. Biotechnol. 260-267.

Sekiguchi, H. (1986). Identification of late-stage phyllosoma larvae of the scyllarid and palinurid lobsters in the Japanese waters. Bull. Jap. Soc. Sci. Fish 52, 1289-1294.

Senevirathna, J.D.M. and Munasinghe, D.H.N. (2012). Phylogenetic status of four spiny lobster species in Southern coastal region of Sri Lanka. Proceedings of NARA Scientific Session. pp. 29.

Smith, M.A., Woodley, N.E., Janzen, D.H., Hallwachs, W. and Hebert, P.D. (2006). DNA barcodes reveal cryptic host-specificity within the presumed polyphagous members of a genus of parasitoid flies (Diptera: Tachinidae). Proceedings of National Academy of Sciences USA, 103, 3657-3662.

Stoeckle, M. (2003). Taxonomy, DNA and the barcode of life. BioSci. 53, 2-3.

Tam, Y.K. and Kornfield, I. (1998). Phylogenetic relationships of clawed lobster genera (Decapoda: Nephropidae) based on mitochondrial 16S rRNA gene sequences. J. Crust. Biol. $18,138-146$. 